\title{
NEK2 Gene
}

National Cancer Institute

\section{Source}

National Cancer Institute. NEK2 Gene. NCI Thesaurus. Code C138104.

This gene plays a role in protein phosphorylation and the cell cycle. 